\title{
Adapting the University Ethical Climate, a Necessity in the Pandemic Context
}

\author{
Teodora DRĂGHICI ${ }^{1}$, Oana-Antonia ILIE ${ }^{*}$
}

\author{
1 Academia Forțelor Terestre "Nicolae Bălcesu", Sibiu, \\ Romania; \\ * Corespondență: antonia_ilie@yahoo.com
}

\begin{abstract}
This paper aims to analyze the consequences of the pandemic crisis measures on the educational system, in terms of the university ethical climate, trying to provide solutions for creating and maintaining an optimal climate for learning and character development. The ethical organizational climate is at the core of the ethical decisionmaking, ethical behavior, and development in the university environment. The university ethical climate reflects the collective moral behaviors, facilitates commitment, respect for ethical norms and integrity of the parties involved in the educational process, leading to the development of an ethical culture of responsibility. In the context of the current pandemic, the educational solutions adopted, although effective in the short term, in the long run can impinge on the basic values the traditional school is built on. An open-door policy is needed more than ever in order to adapt to the new reality generated by the crisis, to keep universities in an area of moral authority, to avoid moral obscurantism and absenteeism, consequences of the evading the responsibility tendency, generated by the online school.
\end{abstract}

Keywords: university ethical climate, pandemic context, ethical culture, responsibility, character development

Rezumat: Lucrarea de față își propune să analizeze consecințele măsurilor crizei pandemice asupra sistemului educațional, în ceea ce privește climatul etic universitar, încercând să ofere soluții pentru crearea și menținerea unui climat optim de învățare și dezvoltare a caracterului. Climatul organizațional etic se află în centrul procesului de luare a deciziilor etice, al comportamentului etic și al dezvoltării în mediul universitar. Climatul etic universitar reflectă comportamentele morale colective, facilitează angajamentul, respectul pentru normele etice și integritatea părților implicate în procesul educațional, conducând la dezvoltarea unei culturi etice a responsabilității. În contextul actualei pandemii, soluțiile educaționale adoptate, deși eficiente pe termen scurt, pe termen lung pot afecta valorile de bază pe care se construiește școala tradițională. Este nevoie mai mult ca oricând de o politică de uși deschise pentru a se adapta la noua realitate generată de criză, pentru a menține universitățile într-o zonă de autoritate morală, pentru a evita obscurantismul și absenteismul moral, consecințe ale sustragerii tendinței de responsabilitate, generate de scoala online.

Cuvinte cheie: climatul etic universitar, contextul pandemic, cultura etică, responsabilitatea, dezvoltarea caracterului
Citation: Drăghici. T, \& Ilie, O.A. (2021). Adapting the University Ethical Climate, a Necessity in the Pandemic Context. Etică și

Deontologie. 1(2), 31-40

https://doi.org/10.52744/RED.2021.02.04

Publisher's Note: RED stays neutral with regard to jurisdictional claims in published maps and institutional affiliations.

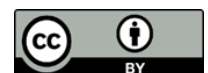

Copyright: (c) 2021 by the authors. Submitted for possible open access publication under the terms and conditions of the Creative Commons Attribution (CC BY) license

(https://creativecommons.org/ licenses/by/4.0/). 


\section{The ethical climate in universities. Theoretical framework}

Ethics generally include impartiality in the performance of duties and resistance to corruption. In the university environment, ethics implies, among other things, the same obligations on the part of all its members. A dictionary definition for "ethics, ethical" shows us that the usual meanings are: 1 . S.Theoretical study of basic principles and concepts in any field of practical thinking and activity. 2. S. Set of rules in relation to which a human group regulates its behavior in order to distinguish what is legitimate and acceptable in achieving goals; moral. 3.Adj. Regarding ethics (1), ethics, based on ethics, according to ethics; moral. (DEX, 1998)

"The field of ethics is the study of how we try to live our lives according to a standard of "right" or "wrong" behavior - in both how we think and behave toward others and how we would like them to think and behave toward us." (Ghillyer, 2010).

Integrity is a path that is distinguished by the fact that it is fair and secure. Only by following this path of ethical integrity, do we not risk becoming the subjects of illicit deeds, by concretely engaging in various forms of legal liability. Same dictionary (DEX, 1998) define integrity as: s.1. Learning to be honest; honesty, probity; incorruptibility.2. The property of being or remaining intact, whole .

Values are used to develop rules that are socially applied within an organization. Integrity, responsibility and trust are examples of such fundamental values (Ferrell et al., 2011). An ethical culture is rooted in an organization's value system. (Grojean, Resick, Dickson, \& Smith, 2004).

Ethical behaviors in an organization are reflected in a wide range of conducts and attitudes including mutual respect, loyalty to the goals and values of the organization, a sense of duty, discipline, punctuality and importance given to moral standards, communication, socialization and organizational performance.

The moral norm represents the duty of every free conscience, which imposes on man to wish, through everything he does or thinks, to be human at the highest level of his possibilities (Mihăilescu, 2019). The specific role of moral norms is the optimization of the human condition and through it, a maximum of socialization.

Climate refers to the atmosphere, mood or feeling, predominant in an organization. We define the ethical climate as the shared perception of norms, values, and practices regarding appropriate ethical behavior by the employees of an organization, influencing their decision making and behavioral response to ethical dilemmas. The organizational climate expresses the perceptions shared by employees that reflect the way they perceive and describe the organizational culture: "Climate is often regarded as the way things are around here" (Vardi, 2001). 
Victor and Cullen's (1988) theoretical research on the ethical climate became the foundation of studies of the ethical climate in organizations. Victor and Cullen's Ethical Climate Theory (ETC) is based on Kohlberg's $(1981,1984)$ work on moral development and Schneider's (1983) work on the organizational climate. They define ethical climate as "the shared perception of what is correct behavior and how ethical situations should be handled in an organization" (Victor \& Cullen, 1987), or "the prevailing perceptions of typical organizational practices and procedures that have ethical content" (Victor \& Cullen, 1988). An ethical organizational climate will reflect employees' perceptions of the ethical values and practices of their organizations.

The ethical philosophical framework of ECT includes the following three ethical theories: egoism, utilitarianism, and deontology. There can be several types of ethical climate in an organization:

1. The egoistic ethical climate - employees' perception that the employer organization generally promotes decisions of personal interest to the detriment of others (Al-Omari, 2012);

2. The utilitarian ethical climate - employees' perception that the employing organization has a personal interest in the well-being of others (Victor \& Cullen, 1988);

3. The deontological ethical climate - the employee perceives that the employing organization is guided by principles, rules and laws (Al-Omari, 2012).

Ethical climates have been shown to have a variety of effects, some positive and some negative, on the ethical behavior. The literature shows that ethical behavior is linked to the ethical climate perceived by employees, and that the ethical climate can be a predictor of their ethical behavior. An ethical climate causes the employee to think more about moral issues, providing a basis for reasoning about what is right to do in various situations; reasoning that is most likely to turn into ethical behavior.

Studying the ethical climate in universities serves to measure and predict ethical behavior in higher education institutions and as an effective strategy for the higher education leadership to better manage the ethical behavior of their employees.

The higher education institution should cultivate an ethical climate based on trust, cultivated and maintained through respect, responsibility, fairness, tolerance, benevolence, care, and establish ethical training, mentoring and communication programs to produce positive ethical decisions and a ethical behavior in its employees, in order to maximize the social benefits of institutions and their stakeholders.

We consider that the role of a modern university is not only to train specialists and researchers, but also civilized, cultivated people, people of character, who respect their peers and institutions, as moral people. An immoral university environment favors the formation of immoral people, while a moral university environment will 
produce moral people. We also believe that students are not and should not be transformed into objects of education, clients or civic associates of teachers, but partners in the common approach of training for performance, increased knowledge and values.

It is obvious and unanimously accepted that the organizational environment or context directly influences the moral behavior (s) of the members of an organization. Universities need to develop an ethical environment and ethical practices at the institutional level, in order to expect ethical behaviors at the individual level. As such, the attention must be directed to the ethics of the university as a whole, and then to the ethics of its members.

\section{Implications and challenges of the pandemic context on the university ethical climate}

The Covid-19 crisis has raised many ethical issues at the institutional level, calling into question the functionality of the traditional education system. The new challenges have prioritized issues such as compliance with hygiene and health standards, health care, protection of employees and students, the duty to prevent the spread of the disease, to detect and treat, to compensate, to care, to inform. In the latter case, scientific knowledge and technology have provided effective solutions. From a human point of view, however, the Covid pandemic is in itself an extraordinary ethical dilemma, and a test for all humanity in terms of global collaboration, crisis management, technology and expertise, decision making, allocation of funds, etc.

In 2019, the Morality and Ethics Advisory Group (MEAG) was established in order to provide independent advice to the government on ethical issues related to health and social assistance. Since the beginning of the pandemic, MEAG has offered solutions to the moral and ethical issues generated by the Covid-19 health crisis. At the level of university, the principles of respect, fairness, impartiality, equal opportunities have been put forward, especially to facilitate decision-making and the management of individual situations.

The basic principle was equal concern and respect for all those involved in the educational and research act. This implies the need to keep people informed about the decisions made and to honor their contribution. Good, respectful communication is fundamental in this regard, in order to ensure that people receive adequate counseling and preparation for change, continuous adaptation and possible new directions or additional responsibilities. A second principle is minimization of harm caused by the crisis and here we refer to the physical, psychological, social and economic damage caused to individuals. The third principle, of fairness, imposes equity as a coordinating principle of the activities of students and staff, regardless of 
their nature. The principle of reciprocity implies that those who are required to take on greater responsibilities such as adapting the content of the teaching and teaching to the online mode should be adequately supported and rewarded by the authorities (Jones, 2020).

What is highlighted here is the emphasis placed on the respect due to all those involved in the educational act and the concern that all individuals, both students and staff be treated equally and equitably.

Beyond the benefits of the technological advancement, the collective enthusiasm to be connected audio and video on educational platforms, the easy distribution of teaching materials and interactive topics, the confusion with traditional education is ethically dangerous.

The ethical issues faced by the Online School Program, the impact on academic integrity, have been reported around the world. The detected problems are not few, ranging from those related to academic honesty, plagiarism and intellectual property, to fraud, collective cheating, gang behavior, fictitious presence, negligence, disrespect. There has been an increase in cases of copying, exchange of information and cheating, especially during exams. The general attitude is one of indifference or lack of interest because students no longer prioritize education over other aspects of their lives. Online education has created an environment permissive to the free distribution of various materials, videos and lectures, without the consent of their author. The lack of direct interaction made students feel less responsible and interested in the integrity and quality of their work. The result was: negligence in solving tasks, unfinished homework, copy-paste solutions, sending answers to other colleagues, alternative pages open for reading during exams, Google Search answers, etc.

Another aspect is related to the unequal treatment or discrimination of those who do not have access to the Internet or who share the same device, and between those familiar with the online environment and those who do not master the electronic means of communication. Thus, a major obligation that occurs is to avoid any inequality resulting from the unavailability of resources.

A problem faced by universities around the world is whether students who study online should pay the same fees as if they were on campus and receive personal training (Barkan, 2020, Demuyakor, 2020, Massa, 2020, Young, 2020). The ethical question we must ask ourselves is: if tuition fees are not reduced to reflect these losses, aren't students overburdened and treated unfairly?

Regardless of the decisions taken by the institutions in order to compensate for the lack of direct interaction, the experience of being a student, the experience of the campus, the relationship with colleagues, teachers, international students, playing sports, etc, were lost, thus, the chance to receive a multilateral, diverse education was certainly diminished. 


\section{Solutions for the ethical climate in the university of the 21st century}

The university environment must become a truly democratic environment based on normative regulation and implementation. Today, among other values, are recognized by regulation as university values the following (Carta, 2016): personal autonomy - art 108, respect and tolerance - art 114, goodwill and care - art 115, necessary in such an environment, though, unfortunately, to a small extent understood and followed.

The university will truly become the main engine of the development of a society and the well-being of its members only if the values enshrined in internal regulations are promoted; if intellectual work and scientific creation are stimulated; each member acts sincerely and correctly; acts of corruption are penalized. Only under such conditions, the future elite of the state can be prepared.

We believe that the social status of a society is largely determined by the economic, intellectual and moral status of universities; the skills acquired by students during their studies should be related to their future ethical and professional becoming, including behavior in public life and in the private one as well.

If, in universities, the culture of the institution is vitiated, in consequence, future students will reproduce and apply: fraud, manipulation, paternalism, influence peddling, the tendency to solve professional problems behind the scenes, will have an attitude of indifference towards colleagues and institution, a clique behavior, they will commit acts of corruption, abuse of office, nepotism, they will be permanently tempted to evade moral rules and legal norms.

In order to create a moral university, it is necessary for it to internalize a series of organizational virtues in all its internal practices and processes, so as to stimulate all members of the academic community to behave ethically and, at the same time, prevent their immoral behaviors. Therefore, a moral university is that which creates a moral context for its members, by developing organizational moral virtues.

We identified four imperative solutions for the ethical university of the $21^{\text {st }}$ century, solutions that impose themselves as valid in any university context, namely: the value-based leadership, the ethical training, the mentoring programs and the ongoing communication.

A values-based leadership is one that inspires "cooperative personal decisions by creating faith in common understanding, faith in the probability of success, faith in the ultimate satisfaction of personal motives, and faith in the integrity of common purpose." (Barnard, 1939). Leadership creates and sets the norm in any organization and it is the first responsible for establishing the adequate ethical climate and the efficient communication among the employees. An efficient leadership:

- is a value based, ethical leadership; 
- uses the power of personal example;

- establishes clear expectancies and behavior norms;

- produces feed-back;

- offers coaching and support;

- acknowledges and rewards the achievements and behaviors that enforce the organizational culture;

- is non-discriminatory and aware of the individual differences among the employees;

- establishes ethical training and mentoring programs.

Ethical training is an essential part in the effort of ensuring a positive ethical climate within an organization. An effective ethical training programme will:

1. Reinforce the organization's culture and standards;

2. Focus on the organization's unique ethical problems;

3. Discuss and solve the particular ethical dilemas;

4. Integrate ethical studies into the entire curriculum.

The mentoring programs will teach the undergraduate or graduate student not only the method of scientific enquiry in academic research but also the values associated with the responsible conduct of research (Horner and Minifie, 2011). They will be responsible with and provide counseling in the following:

1. Explaining the fundamental ethical and deontological values;

2. Providing support in solving personal and organizational ethical dilemmas;

3. Encouraging ethical behavior.

Mentorship programs will prepare students to solve ethical dilemmas within organizations and avoid negative consequences of non-ethical behavior, improve ethical thinking, moral awareness and ethical leadership. Mentors must also provide guidance in writing scientific papers, presentations in professional conferences or public communications, securing of research grants.

Last but not least, ongoing communication is necessary for enabling the transfer and reinforcement of the organizational values. We consider as vital for the perpetuation of an the ethical climate the following:

1. Consistent communication on the fundamental ethical and deontological values;

2. Periodically reminding and revising the Ethical Code of the university;

3. All members' participation to the elaboration/ modification of the amendments of the University Ethical Codes. 
In 1999, the National Communication Association officially adopted the Credo for Ethical Communication. The NCA Credo for Ethical Communication considers as essential for the ethics of human communication the following principles:

"We advocate truthfulness, accuracy, honesty, and reason as essential to the integrity of communication.

We endorse freedom of expression, diversity of perspective, and tolerance of dissent to achieve the informed and responsible decision making fundamental to a civil society.

We strive to understand and respect other communicators before evaluating and responding to their messages.

We promote access to communication resources and opportunities as necessary to fulfill human potential and contribute to the well-being of families, communities, and society.

We promote communication climates of caring and mutual understanding that respect the unique needs and characteristics of individual communicators.

We condemn communication that degrades individuals and humanity through distortion, intimidation, coercion, and violence, and through the expression of intolerance and hatred.

We are committed to the courageous expression of personal convictions in pursuit of fairness and justice.

We advocate sharing information, opinions, and feelings when facing significant choices while also respecting privacy and confidentiality.

We accept responsibility for the short- and long-term consequences of our own communication and expect the same of others" (NCA, 1999).

Truthfulness and honesty are considered among the most important principles of ethical communication; thus, being open and transparent and adopting an opendoor policy with other partner organizations and the media is key to professional trustworthiness and integrity, leading to a positive reputation and to the organization's visibility. Adopting the above-mentioned solutions within an organization will result in increased trust among the employees and alignment with the enterprise's code of conduct.

\section{Conclusions}

We conclude with some useful recommendations, generally valid for universities that are responsible of forming the elite of the society:

Firstly, the University Code of Professional Ethics and Ethics, enshrined in each university, is a set of consensual moral rules of members and functions as a moral 
contract between the members of the academic community - art. 104, paragraph (1) and paragraph (2) (Carta, 2016). In order for the previously presented ones to materialize, it is important for all the members of the community to participate in the elaboration, and later in the modification of the university ethics codes, in the contexts that require it.

Secondly, we consider that the pandemic caused by the COVID-19 virus, has generated unregulated situations yet, as such it is necessary to adapt the internal university regulations with the particularities outlined during the years 2020-2021.

Thirdly, although ethical and deontological values, such as: "academic freedom, personal autonomy, justice and fairness, merit, academic honesty and intellectual fairness, transparency, personal, professional and social responsibility, respect and tolerance, goodwill and care" (Carta, 2016), are enshrined in law, they are not explicit, we often find them only mentioned, leaving the possibility for the members of the academic community to bring them a personal and varied interpretation, which has led and will often lead to a violation of moral and legal rules.

Fourthly, we consider that it is not enough to post the Code of Ethics on the universities' website, its content must be periodically reiterated to the members of the academic community, especially if it requires or supports changes imposed at national or university level.

Fifth, in the context of university training and undergraduate programs, we consider it necessary that the discipline of Ethics and academic integrity become a compulsory discipline for students starting from the first year of study; today, it is one of the optional subjects, according to the ministerial order no. 3131 of 2018 (Ordin, 2018). 


\section{Referințe}

Barnard, Chester (1939), Dilemmas of Leadership in the Democratic Process, Pub. under the University Extension Fund, Herbert L. Baker Foundation, Princeton University.

Carta, (2016). Carta Academiei Forțelor Terestre „Nicolae Bălcescu”, Sibiu, Codul de etică și deontologie profesională, 2016

Constituția României, published in M.Of.nr.767/31.10. 2003, part I

Craig, E.J., (2015), Meeting the Ethical Challenges of Leadership, Casting Light or Shadow, fifth Edition, Sage Publications, Inc.

DEX, (1998). Dicționarul explicativ al limbii române, second edition, published under the auspices of the Romanian Academy - Iorgu Iordan Institute of Linguistics, București, Universul Enciclopedic Publishing House.

Ghillyer, A., (2014), Business Ethics Now, Mc Graw Hill Education, 5th edition.

Jones, D.G., (2020), Ethical Responses to the Covid-19 Pandemic: Implications for the Ethos and Practice of Anatomy as a Health Science Discipline, Anat Sci Educ 13:549-555, https://doi.org/10.1002/ase.2003, p. 550-551.

Mihailescu, N., (2019), Managementul eticii în instituția școlară, https://ust.md/wpcontent/uploads/2019/12/autoreferat-mihailescu.pdf

NCA, (1999). Credo for Ethical Communication, approved by National Communication Association (NCA) Legislative Council, November https://open.lib.umn.edu/ publicspeaking/chapter/2-2-ethics-in-public-speaking

Ordin, (2018). Ordinul de ministru nr. 3.131/2018 on the inclusion in curricula, for all universities study programs organized by higher education institutions in the national education system, of courses on ethics and academic integrity, M.O.

Vardi, Y., (2001), The effects of organizational and ethical climates on misconduct at work, Journal of Business Ethics 29 (4):325 - 337

Victor, B, Cullen, J.B, (1987), A Theory and Measure of Ethical Climates in Organizations, Research in Corporate Social Performance and Policy, 9.

Victor, B, Cullen, J.B (1988). The Organizational Basis of Ethical Work Climates, Administrative Science Quarterly, 33. 


\title{
Etică bancară. Codul de conduită al înalților funcționari ai Băncii Centrale Europene
}

\section{Carmen Adriana GHEORGHE1*}

\author{
1 Universitatea Transilvania din Braşov. \\ *Corespondență: carmenadrianagheorghe@yahoo.com
}

Citation: Gheorghe, C.A, Etică

bancară. Codul de conduită al înalților funcționari ai Băncii Centrale Europene

Etică și Deontologie. 1(2), 41-49 https://doi.org/10.52744/RED.2021.02.05

Publisher's Note: RED stays neutral with regard to jurisdictional claims in published maps and institutional affiliations.

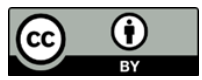

Copyright: (C) 2021 by the authors. Submitted for possible open access publication under the terms and conditions of the Creative Commons Attribution (CC BY) license (https://creativecommons.org/licens es/by/4.0/).
Rezumat: Integrarea finanțării - ca fundament al funcționării progresiste a societății umane - impune, în prezentul aflat în crize multiple, ca cerințele unui comportament etic să fie asimilate activității bancare. Noțiunile care aparțin sferei demnității umane - etică, integritate, morală- trebuie să fie integrate organic celor specifice băncii - risc, fonduri bănești, creditare, supraveghere bancară. Acest proces de impunere a culturii etice în afacerile bancare s-a accentuat începând cu anul 2015, când Banca Centrală Europeană, ca nucleu al sistemului bancar european, a emis un Cadru Etic aplicabil la nivelul Sistemului European al Băncilor Centrale, al Eurosistemului și al Mecanismului Unic de Supraveghere. Pornind de la faptul că, în România, băncile se află într-un regres al reputației și al încrederii, prezentul studiu tratează rolul și importanța Codului de conduită pentru înalții funcționari ai Băncii Centrale Europene, introdus în 2019, act normativ având în centrul său noțiunile de interes public și standarde de integritate

Cuvinte cheie: Banca Centrală Europeană, cadru etic, cod de conduită, cultură etică

Abstract: The integration of financing - as a foundation of the progressive functioning of human society - requires in the present one in multiple crises that the requirements of an ethical behavior be assimilated to the banking activity. The notions that belong to the sphere of human dignity - ethics, integrity, morality - must be organically integrated with those specific to the bank - money, credit, banking supervision. This process of imposing an ethical culture in banking has intensified since 2015, when the ECB, as the core of the European banking system, issued an Ethical Framework applicable to the ESCB, the Eurosystem and the SSM. In Romania, banks are in a decline in reputation and trust. The role of the Code of Conduct for senior ECB officials introduced in 2019 is the subject of this study, focusing on the notions of public interest and integrity standard. The role of the Code of Conduct for senior ECB officials introduced in 2019 is the subject of this study, focusing on the notions of public interest and integrity standard.

Keywords: European Central Bank, ethical framework, code of conduct, ethical culture 


\section{Introducere}

Cele trei entități financiare fundamentale ale Uniunii Europene (U.E): Sistemului European al Băncilor Centrale (S.E.B.C.), Mecanismul Unic de Supraveghere (M.U.S.) și Eurosistemul, au în centrul funcționării administrative și instituționale Banca Centrală Europeană (B.C.E.) Cu un statut definit de obiectul principal - asigurarea stabilității prețurilor - B.C.E. este independentă politic astfel încât sistemul monetar al zonei euro să se afle în centrul politicii sale monetare. Statutul S.E.B.C. (Statut, 2016) și Tratatul privind funcționarea U.E. conțin cei cinci piloni ai independenței funcționale (TFUE, 2012): independența instituțională, independența personală și operațională, independența financiară, independența organizațională și independența juridică

Independența personală le garantează membrilor Consiliului guvernatorilor siguranța mandatului și le permite să evite orice conflicte de interese. În această privință, Statutul S.E.B.C./B.C.E. protejează independența personală a organelor de decizie ale B.C.E. prin prevederea unor contracte pe durată determinată relativ îndelungate și prin interzicerea revocării din funcție pe baza rezultatelor unor politici aplicate anterior. În acest sens, se consideră esențial ca guvernatorii băncilor centrale să dețină mandate semnificativ mai lungi decât cele ale politicienilor; astfel, guvernatorii băncilor centrale pot avea în vedere un orizont mai îndepărtat, concentrându-se asupra aspectelor pe termen mediu, în timp ce politicienii au obiective pe termen mai scurt, în concordanță cu ciclurile electorale.

Independența financiară este asigurată prin bugetul propriu al B.C.E., care este independent de cel al U.E., și prin subscrierea și vărsarea integrală a capitalului B.C.E. de către băncile centrale naționale din cadrul Eurosistemului. Legitimitatea democratică a băncilor centrale independente este reglementată diferit în funcție de fiecare sistem democratic.

Legitimitatea democratică a B.C.E./S.E.B.C., poate fi evidenţiată prin trei elemente. În primul rând, ratificarea Tratatului și a amendamentelor aduse statutelor băncilor centrale naționale de legislația națională, în al doilea rând, numirea membrilor Consiliului guvernatorilor, alcătuit din membrii Comitetului executiv al B.C.E. și din guvernatorii băncilor centrale naționale, de către instituții democratice. Președintele B.C.E. și ceilalți membri ai Comitetului executiv pot fi audiați de comisiile competente ale Parlamentului European, fie la solicitarea Parlamentului, fie la solicitarea acestora.

Deținând personalitate juridică și cu un spectru al independenței atât de larg, se nasc firesc o serie de întrebări legitimate de libertatea membrului/cetățeanului din 
statul membru: „Care sunt limitele între care această independență ce tinde spre absolut, se poate cantona?” „Cum acționează resursa umană a Băncii Centrale de la cel mai înalt nivel, astfel încât să ofere un exemplu personal de integritate morală?”, „Este etica de domeniul afacerilor? Cum facem să se aplice activității bancare standardele etice?" ș. a.

Pentru a răspunde la aceste întrebări, este necesară stabilirea cadrului legislativ, a unui scurt istoric al acestuia, stabilirea rolului Comitetului de etică al B.C.E și a documentelor emise de acesta.

\section{Etica bancară. Cadru legislativ}

Dacă analizăm prevederile instituționale ale B.C.E. vom observa ca acestea au ca scop reglementarea elementelor esențiale pentru funcționarea băncii (Morra \& al., 2017): Comitetul Executiv, Consiliul General și Consiliul de Supraveghere. Aceste norme sunt cuprinse în Decizia Băncii Centrale Europene din 1999 privind Regulamentul de procedură al Comitetului executiv la Băncii Centrale Europene (Decizie BCE, 1999), Decizia Băncii Centrale Europene din 2004 de adoptare a Regulamentului de procedură al Consiliului general al Băncii Centrale Europene (Decizie BCE, 2004a), Versiunea consolidată a Deciziei Băncii Centrale Europene din 2004 de adoptare a Regulamentului de procedură al Decizia Băncii Centrale Europene (Decizie BCE, 2004b), Versiunea consolidate a Regulamentului de procedură al Consiliului de supraveghere al Băncii Centrale Europene (Regulament, 2020).

Încercările de standardizare a conduitei bancare au apărut în 2001, odată cu propunerea Primului cod de conduită - Codul specific de conduită pentru membrii Consiliului guvernatorilor, revizuit în 2006, au continuat cu un Cod suplimentar de criterii etice pentru membrii Comitetului executiv în 2006, revizuit în 2019, și cu un Cod de conduită pentru membrii Consiliului de supraveghere în 2014 (Cod, 2019; Moschella, \& Diodati, 2020).

În altă categorie se încadrează Codul etic consolidat pentru membrii personalului (Cod, 2015), înfiițarea Biroulului de conformitate și guvernanță (Cod, 2019) și înființarea Comitetului de etică la nivel înalt în anul 2015 (Decizie, 2015). Vorbim deci de includerea termenului de "etică" la B.C.E. abia din anul 2015, pe de o parte pentru înalții funcționari, pe de altă pentru membrii personalului (Pogace, 2014).

În sfârșit, pentru M.U.S. și Eurosistem au fost prevăzute standarde minime commune în: Orientarea (U.E.) 2015/855 a B.C.E. (Orientare, 2015a) și Orientarea (U.E.) 2015/856 a B.C.E (Orientare, 2015b). 


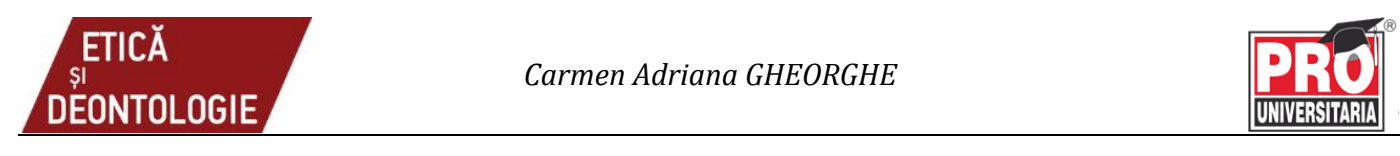

$\mathrm{Cu}$ toate acestea, anul 2019 este marcat de adoptarea cadrului etic al acestor entități de conducere a B.C.E., ceea ce presupune că normele eticii ar putea fi răspunsul la întrebarea privind limitele independenței B.C.E.

În lumina celor anterior prezentate, să interpretăm intervenția din 2015 a B.C.E, de finanțare a celor patru bănci elene aflate în criză - din România și din Bulgaria ca cel din urmă gest de încălcare a eticii bancare pe care l-ar putea săvârși? (Mediafax, 2015). Puțin probabil. Dacă aceste active ar fi fost trecute sub controlul băncilor centrale naționale, băncile-mamă din Grecia ar fi fost afectate imediat, ceea ce ar fi putut da o lovitură finală sistemului financiar elen. Secretul acestei operațiuni de finanțare, tăcerea Băncilor Centrale din România și Bulgaria dau încă de gândit cu privire la conduita etică a industriei bancare de la cel mai înalt nivel. Iar faptul că linii swap similare, prin care băncile centrale se pot împrumuta de la B.C.E. pentru a reîmprumuta bani pe piața locală au mai fost utilizate în perioada crizei financiare din zona euro, dar au fost anunțate public- se interpretează în sensul că interesele B.C.E., mai précis conflictele de interese și încălcările deontologiei bancare europene sunt încă prezente în realitatea financiar-bancară (Fassin \& Gosselin, 2011).

Intrarea în vigoare a Codului de conduită trebuie să facă legătura între noțiuni cu caracter nepatrimonial și cele care țin de activitatea bancară, patrimoniale prin esență. Credibilitatea, încrederea, reputația, etica profesională pot fi reduse la profit sau sferele de aplicare rămân în continuare paralele?

\section{Domeniul de aplicare a Codului. Puterea exemplului și declarația de conduită etică}

Intrarea în vigoare a unui Cod unic urmărește să reflecte cele mai bune practici din domeniul băncilor centrale, din sfera suprevegherii, să reflecte caracteristicile B.C.E. și independența acesteia. Codul de conduită pentru înalții funcționari ai B.C.E. nu aduce atingere normelor etice mai stricte aplicabile membrilor și supleanților în virtutea dreptului național. Un exemplu ar fi Codul de Conduită al industriei bancare din România, din 2018, care revizuiește Codul de Etică Bancară aprobat în anul 2009 (Cod, 2018).

Aprobarea Codului de către Consiliul Guvernatorilor impune, pentru membrii organelor de conducere, principiul puterii exemplului și norme unice pentru întreaga resursă umană a B.C.E.

Structurat pe două direcții principale - Domeniul de aplicare și Standardele propriu zise - Codul pentru conduită pentru Înalții funcționari ai B.C.E. „urmărește punerea în aplicare a celor mai înalte standarde de etică profesională, asigurând astfel că membrii organismelor sale de nivel înalt conduc prin puterea exemplului și inspiră 
angajații din cadrul Eurosistemului, S.E.B.C. și M.U.S. să respecte astfel de standarde în exercitarea atribuțiilor lor" (Preambul, pct.9).

Domeniul de aplicare se referă la organisme B.C.E. de nivel înalt, respectiv la Consiliul Guvernatorilor B.C.E., Comitetul Executiv al B.C.E. și Consiliul de Supraveghere al B.C.E.

Se supun prevederilor Codului două categorii de membri - membrii și supleanții din cadrul reuniunilor Consiliului Guvernatorilor sau din Consiliul de Supraveghere, pe de o parte, și membrii Consiliului General, ai Comitetului de audit, ai Comitetului de etică și ai Comitetului administrativ de control, pe de altă parte, aceștia fiind obligați să semneze declarația de conduită etică. Fac excepție, și în consecință nu au obligația de a semna declarația de conduită etică, membrii personalului B.C.E. care participă la reuniunile organismelor B.C.E. de nivel înalt și care fac obiectul cadrului etic.

Însoțitorii care participă la reuniunile Consiliului Guvernatorilor sau ale Consiliului de Supraveghere nu se supun acestei obligații, însă, înainte de a participa pentru prima dată la oricare dintre reuniuni, semnează o declarație de conduită etică care cuprinde: principiul general al evitării conflictelor de interese, interzicerea utilizării informațiilor confidențiale și normele privind secretul profesional,

Articolele 3-18 din Partea a II-a a Codului au ca fundament principiile activității B.C.E.: (i) secretul profesional și (ii) separarea funcției de supraveghere de funcția de politică monetară, fiind reglementate șase aspect principale: activitatea privată și mandatele oficiale, relațiile cu grupurile de interes, aparițiile publice și declarațiile publice, declarațiile de interese. În baza acestora, obligațiile asumate privind conduita etică sunt incidente și după încetarea îndatoririlor și responsabilităților față de B.C.E.

\section{Rolul Comitetului de etică al B.C.E.}

În prezent, Comitetul de etică al B.C.E., instituit prin Decizia (UE) 2015/433 a Băncii Centrale Europene are ca atribuții (Claveau \& al., 2018):

1. Emite avize în situațiile în care există îndoieli cu privire la dispozițiile codului și, atunci când este cazul, cu privire la aplicarea practică a Codului.

De exemplu, membrii și supleanții solicită Comitetului de etică să emită un aviz referitor la perioadele de incompatibilitate care li se aplică în temeiul prevederilor din Cod, înainte de se implica într-o viitoare activitate profesională remunerată. Comitetul de etică poate recomanda în aviz:

- fie să se renunțe la perioadele de incompatibilitate, fie să se scurteze durata acestora atunci când circumstanțele legate de posibilitatea unor conflicte de interes rezultate din activităţile profesionale remunerate ulterioare permit acest lucru; 
- să se prelungească cu până la maximum doi ani, în cazul membrilor, și cu un an, în cazul supleanților, perioadele de incompatibilitate prevăzute la articolul 17.1 litera (a) și la articolul 17.2 litera (a). Această prelungire a perioadei de incompatibilitate se instituie:

a) în cazul activităților profesionale remunerate ulterioare relevante la instituții de credit semnificative sau mai puțin semnificative, în a căror supraveghere membrul sau supleantul a fost direct implicat,

b) în cazul în care, există posibilitatea unor conflicte de interes rezultate din astfel de activități profesionale remunerate.

Avizele emise de Comitetul de etică în baza articolelor 17.3 și 17.4 din Cod sunt transmise Consiliului guvernatorilor. Apoi, Consiliul guvernatorilor face o recomandare autorității naționale competente sau băncii centrale naționale relevante, care va informa Consiliul guvernatorilor cu privire la orice impediment în implementarea recomandării respective.

2. Primește informări privind impedimente în respectarea Codului, inclusiv cu privire la orice impediment care rezultă din dispoziții de drept național aflate în conflict.

Astfel, membrii și supleanții informează în scris Comitetul de etică în legătură cu:

- orice activități private pe care intenționează să le desfășoare

- activitățile private și mandatele oficiale în curs ale acestora

Membrii și supleanții informează în scris, fără întârzieri nejustificate, pe președintele organismului B.C.E. de nivel înalt și Comitetul de etică cu privire la orice situație care ar putea da naștere unor preocupări legate de conflicte de interese. În special, aceștia se recuză de la a lua parte la orice discuție, deliberare sau vot cu privire la orice astfel de situație, nefiindu-le furnizată niciun fel de documentație aferentă.

0 altă situație se referă la soți, soții, partenere și parteneri. Astfel, membrii și supleanții informează în scris, de îndată, pe președintele organismului B.C.E. de nivel înalt relevant și Comitetul de etică cu privire la orice activitate profesională sau altă activitate remunerată desfășurată de soții/soțiile sau partenerii/partenerele acestora care ar putea da naștere unor preocupări legate de conflicte de interese (Demmke \& Henökl, 2007).

În sfârșit, înalților funcționari le revin obligații etice cu privire la cadouri. Membrii Comitetului executiv, președintele Consiliului de supraveghere și reprezentanții B.C.E. în Consiliul de supraveghere înregistrează, fără întârzieri nejustificate, la secretarul Comisiei de etică, orice cadou sau ofertă de cadou primită, indiferent de valoare. Alți membri și supleanți se supun normelor procedurale naționale aplicabile în materie de înregistrare a cadourilor. 
Tranzacțiile financiare efectuate de înalții funcționari sunt și ele monitorizate. Membrii și supleanții fac obiectul raportării și monitorizării conformității în legătură cu tranzacțiile financiare private ale acestora, astfel cum se prevede în normele procedurale naționale aplicabile, și transmit anual Comitetului de etică o confirmare scrisă a faptului că s-au conformat normelor procedurale naționale aplicabile privind tranzacțiile financiare private și că raportarea și monitorizarea conformității în legătură cu tranzacțiile financiare private ale acestora s-au efectuat în conformitate cu normele procedurale naționale aplicabile.

Efectele aplicării Codului se prelungesc și după încheierea mandatului. Membrii informează în scris președintele organismului B.C.E. de nivel înalt în cauză și Comitetul de etică cu privire la intenția lor de a se implica în orice activitate profesională remunerată în cursul perioadei de doi ani de la încheierea mandatului acestora sau de la data încetării calității lor de membru al unui organism al B.C.E. de nivel înalt.

\section{Obligații etice specifice}

Având un interes real ca membrii săi să adere și să se supună acelorași norme de conduită profesională, B.C.E. urmărește ca ansamblul standardelor etice să se aplice atât pe durata mandatului, cât și după încetarea raporturilor de muncă.

Dintre obligațiile etice din timpul exercitării mandatului sau al deținerii calității de membru al unui organism B.C.E. de nivel înalt, amintim:

- Informațiile confidențiale (adică secretul profesional sau informațiile sensibile) nu pot fi divulgate altfel decât deliberat, ca parte a strategiei de comunicare convenite a B.C.E. O grijă deosebită trebuie avută cu privire la divulgarea de informații confidențiale în discursuri sau declarații publice sau prin transmiterea acestora către mijloacele de informare în masa. În această situație astfel de informații se tratează în conformitate cu normele interne convenite cu privire la tratamentul informațiilor sensibile ale S.E.B.C. și M.U.S.

- Separarea supravegherii prudentiale de orice altă functie. Aceasta înseamnă că membrilor și supleanților din organismele B.C.E. le revine obligația separării supravegherii prudențiale de orice altă funcție, inclusiv față de atribuțiile de politică monetară (Decizie, 2014).

- Evitarea conflictului de interese, care este definit relativ la activitatea profesională remunerată a soțului sau partenerului, iar avantajele sunt considerate cadourile, ospitalitatea, premiile, titlurile, decorațiile, invitațiile la evenimente.

- Neutilizarea informațiile confidențiale în beneficiu propriu sau în beneficiul unui terț la efectuarea tranzacțiilor financiare de către membrii și supleanții, 
inclusiv atunci când aceste tranzacții financiare au caracter privat și indiferent dacă astfel de tranzacții se efectuează direct sau prin intermediul unui terț, atât pe risc și în nume propriu, cât și pe riscul și în numele unui terț.

În ceea ce privește obligațiile care revin după încetarea relațiilor de muncă, cele mai importante sunt:

- obligația de informare. În conformitate cu prevederile art. 17 punctele 1-7, timp de doi ani de la încheierea mandatului sau de la data încetării calității de membru al unui organism al B.C.E. de nivel înalt membrii informează în scris organismul B.C.E. și Comitetul de etică despre intenția lor de a se implica în orice activitate profesională remunerată.

- obligația depunerii unei declarații pe propria răspundere. În plus față de obligația de informare, membrii și supleanții transmit anual Comitetului de etică, pe durata perioadei de notificare de un an sau de doi ani de la încetarea mandatului acestora, o declarație pe propria răspundere semnată în care confirmă activitățile lor profesionale remunerate și remunerația respectivă, un raport în acest sens fiind prezentat președintelui.

\section{Concluzii}

Intervenția crizei pandemice la începutul anului 2020 a diminuat intenția celor mai înalte organisme financiar-bancare din U.E. de a reglementa aspectele imorale, de corupție și abatere de la etica profesională a resurselor umane cu funcții de conducere din B.C.E. Atâta timp cât codul conține prevederi amănunțite cu privire la faptele care pot constitui o conduită neetică și doar o singură sancțiune - mustrarea - urmată, eventual, de un anunț public, rolul Codului de conduită a înalților funcționari din B.C.E. rămâne destul de diluat.

\section{Referințe}

Claveau, F., Dietsch, P., \& Fontan, C. (2018), The ethics of central banking. In The Routledge Handbook of Ethics and Public Policy, pp. 178-190, Routledge.

Cod, (2015), Cadrul etic al BCE. https://eur-lex.europa.eu/legal-content/RO/TXT/?uri= uriserv\%3AOJ.C_.2015.204.01.0003.01.RON\&toc=0J\%3AC\%3A2015\%3A204\%3ATOC

Cod, (2018), Codul de Conduită al industriei bancare din România, din 2018, care revizuiește Codul de Etică Bancară aprobat în anul 2009, pe site-ul A.R.B., https://www.arb.ro/wpcontent/uploads/7-Cod-de-conduita-ARB.pdf

Cod, (2019), Cod de conduită pentru înalții funcționari ai Băncii Centrale Europene, https://eurlex.europa.eu/legal-content/RO/TXT/PDF/?uri=CELEX:52019XB0308(01)\&from=EN

Decizie BCE, (1999), Decizia Băncii Centrale Europene din 12 octombrie 1999 privind Regulamentul de procedură al Comitetului executiv al Băncii Centrale Europene, OJ L 314, 8.12.1999, p. 34-35. 
Decizie BCE, (2004a), Decizia Băncii Centrale Europene din 17 iunie 2004 de adoptare a Regulamentului de procedură al Consiliului general al Băncii Centrale Europene (BCE/2004/12) OJ L 267M , 12.10.2005, p. 15-17.

Decizie BCE, (2004b), Decizia Băncii Centrale Europene din 19 februarie 2004 de adoptare a Regulamentului de procedură al Băncii Centrale Europene.

Decizie, (2015), Decizia (UE) 2015/433 a Băncii Centrale Europene din 17 decembrie 2014 privind instituirea unui Comitet de etică și regulamentul de procedură al acestuia. JO L 70, 14.3.2015, p. 58.

Demmke, C., \& Henökl, T. (2007), Managing Conflicts of Interests-Ethics Rules and Standards in the Member States and the European Institutions. EIPAScope, 2007(3), 1-7.

Fassin, Y., \& Gosselin, D., (2011), The collapse of a European bank in the financial crisis: An analysis from stakeholder and ethical perspectives. Journal of business ethics, 102(2), 169-191.

Mediafax, (2015), BCE a creat linii secrete de finanțare către România și Bulgaria, pentru băncile elene. https://www.digi24.ro/stiri/externe/mapamond/bce-a-creat-linii-secrete-definantare-catre-romania-si-bulgaria-pentru-bancile-elene-416749

Morra, C.B., Smits, R., \& Magliari, A., (2017), The administrative board of review of the European Central Bank: experience after 2 years. European Business Organization Law Review, 18(3), 567-589.

Moschella, M., \& Diodati, N.M., (2020), Does politics drive conflict in central banks' committees? Lifting the veil on the European Central Bank consensus. European Union Politics, 21(2), 183-203.

Orientare, (2015a), Orientarea (UE) 2015/855 a Băncii Centrale Europene din 12 martie 2015 privind principiile unui Cadru etic al Eurosistemului și de abrogare a Orientării BCE/2002/6 privind standardele minime aplicabile Băncii Centrale Europene și băncilor centrale naționale cu ocazia efectuării operațiunilor de politică monetară, a operațiunilor de schimb cu rezervele valutare ale BCE și a gestionării activelor din rezervele valutare ale BCE. JO L 135, 2.6.2015, p. 23.

Orientare, (2015b), Orientarea (UE) 2015/856 a Băncii Centrale Europene din 12 martie 2015 privind principiile unui Cadru etic pentru Mecanismul unic de supraveghere. JO L 135, 2.6.2015, p. 29.

Pogace, E., (2014), The Role of Ethics for Central Bank Senior Management: A Comparative Analysis of Recent Developments. Int'l. In-House Counsel J., 8, 1.

Regulament, (2020), Regulamentul de procedură al Consiliului de supraveghere al Băncii Centra, EUR-Lex - 02014Q0621(01)-20200727 - EN - EUR-Lex (europa.eu)

TFUE, (2021), Tratatul privind funcționarea Uniunii Europene. Jurnalul Oficial al Uniunii Europene, 26.10.2012, https://eur-lex.europa.eu/resource.html?uri=cellar:2bf140bfa3f8-4ab2-b506-fd71826e6da6.0001.02/DOC_2\&format=PDF

Statut, (2016), PROTOCOLUL (nr. 4) PRIVIND STATUTUL SISTEMULUI EUROPEAN AL BĂNCILOR CENTRALE ȘI AL BĂNCII CENTRALE EUROPENE. OJ C 202, 7.6.2016, p. 230-250 